\title{
Productive and Adaptive Qualities of Saanen Goats In Tyumen Oblast
}

\author{
Svyazhenina M.A. \\ Department of Animal Production Manufacture and \\ Processing Technologies \\ Northern Trans-Ural State Agricultural University \\ Tyumen, the Russian Federation \\ Ponomareva E.A. \\ Department of Animal Production Manufacture and \\ Processing Technologies \\ Northern Trans-Ural State Agricultural University \\ Tyumen, the Russian Federation
}

\author{
Tatarkina N.I. \\ Department of Animal Production Manufacture and \\ Processing Technologies \\ Northern Trans-Ural State Agricultural University \\ Tyumen, the Russian Federation \\ Chasovschikova M.A \\ Department of Animal Production Manufacture and \\ Processing Technologies \\ Northern Trans-Ural State Agricultural University \\ Tyumen, the Russian Federation
}

\begin{abstract}
Dairy goat farming is one of the promising areas of animal farming. Modern milk production necessitates not only certain technical solutions in production arrangement, but primarity high yield animals adapted to industrial production. Saanen is one of the most fitting breeds for milk production. This paper characterizes the Saanen goats of Kizerov farming enterprise, Tyumen oblast. The research results support possibility of adapting this breed of goats to the region's climatic conditions. This conclusion is supported by the fact that despite lower milk yield (by $\mathbf{2 7 . 4 \%}$ as compared to mothers), dams at the farm has shown high scores in fat and protein content of milk. The production of young stock was $7.3-25.0 \%$ lower than the recommended values. However, at the age of 1.5 years, the rearing stock corresponded to elite class by its weight and had harmonious built similar to that of the adult nannies while having insignificantly smaller sizes. The selection coefficients obtained allows conducting early picking of animals for both exterior and daily milk yield with the aim to form a high yield breed herd. The studies of polymorphism in blood proteins and enzymes revealed a high level of uniformity of the herd, thus confirming its breed and allowing recommending to introduce some fresh blood with the aim to increase the genetic variability of the herd.
\end{abstract}

Key words - milk production, Saanen breed, adaptation.

\section{INTRODUCTION}

Modern animal farming shall be a source of high quality and versatile foodstuffs [1]. Milk production is largely based on utilizing cattle in large industrial enterprises and small farms. However, some features of cow milk productivity, as well as appearance of allergic reactions to daily products produced from cow milk stimulate considering production of dairy products from other farm animals.

Recently, more attention is paid to goat milk production as a sector providing high quality primary milk produce for food industry $[2,3]$. At that, goat farming has its specifics in farm management, from large industrial enterprises to small personal farms. To develop the sector in Russia, a program has been developed, Development of sheep and goat breeding in Russia in 2012-2014 and prospects up to 2020, that aims at bringing the headcount of milk goats up to 1.4 million animals [4-6].

One of the most common milk breeds is Saanen, which has a large area of distribution and is bred in many countries globally. This breed is characterized with good adaptability, both to large industrial-scale enterprises and smaller farms [7, $8,9]$. Enterprises breeding this breed of goats has appeared in Tyumen oblast as well. However, climate of Western Siberia is quite harsh and not just complicates climatic adaptation, but also imposes limits for feed resources (mainly in fodder quality). Taken all together, these conditions extend influence over animals imported into the region and reflects on their productivity. Thus, studies of productive and farming indicators of the imported animals and their progeny characterize not only the productivity potential, but animal adaptability as well, which is important for development of the sector. Besides, the research results shown are timely for creation of a future pedigree foundation for milk goat breeding in the region.

\section{MATERIALS AND METHODS}

The research has been conducted on a herd of Saanen breed goats of Kizerov farming enterprise, Tyumen oblast. The herd was formed in 2011, by importing the livestock from Germany. Average productivity of the nuclear stock was $748 \mathrm{~kg}$ of milk with fat content of $4.68 \%$ and protein content of $3.43 \%$. During the research that followed common methodology, the authors studied exterior, milk productivity, reproductive qualities of goats and relationship between the milk productivity indicators. Immunogenotypic analysis of blood of the animals $(n=141)$ has been conducted in the Immunogenetics and DNA laboratory of the All-Russian R\&D Institute of Sheep and Goat Breeding for four polymorphic systems of blood proteins and enzymes: transferrin (Tf), hemoglobin (Hb), arylesterase (AEs), Alkaline phosphatase (Ap). 


\section{RESEARCH RESULTS}

\section{A. Exterior of Saanen goats}

Exterior attributes characterize not only external appearance of animals, but also their built and, indirectly, their productive qualities. During the valuation of animals, mainly their built and live weight are assessed. Saanen goats have a specific exterior, namely: rather big size, dryness and prominent milk forms. The animals are white, predominantly polled. All the above mentioned attributes were characteristic of the animals at the enterprise. Animal measurement results are listed in Table 1.

TABLE 1 MEASUREMENTS OF SAANEN DAMS, CM

\begin{tabular}{|l|c|c|c|}
\hline \multicolumn{1}{|c|}{ Measurement } & $\begin{array}{c}\text { Recommend } \\
\text { ed for the } \\
\text { breed }\end{array}$ & $\begin{array}{c}\text { Herd } \\
\text { average }\end{array}$ & $\begin{array}{c}\text { Nuclear } \\
\text { stock }\end{array}$ \\
\hline Height at hips & 77 & $69.5 \pm 0.87$ & $72.6 \pm 0.38$ \\
\hline Height at the withers & 76 & $65.8 \pm 0.33$ & $67.7 \pm 0.61$ \\
\hline Chest girth & 88 & $90.8 \pm 0.45$ & $95.6 \pm 1.10$ \\
\hline Body length & 81 & $82.5 \pm 0.52$ & $87.3 \pm 1.05$ \\
\hline Hook bone width & 17 & $17.3 \pm 0.17$ & $18.1 \pm 0.30$ \\
\hline Chest width & 18 & $20.5 \pm 0.18$ & $21.7 \pm 0.34$ \\
\hline
\end{tabular}

Animals at the farm, of German selection, whose representatives somewhat differ in measurements from average recommended parameters of the Saanen breed. The main differences are somewhat shorter height, but a longer and wider body. Such features are mostly characteristic of rather crude animals. The goats selected for the nuclear stock are somewhat larger than the herd average, but pertain to the same type.

Breeder bucks used at the farm had the same features, which was confirmed with measurements. Height at the withers was $76 \mathrm{~cm}$ (cf. $84-95 \mathrm{~cm}$ recommended), height at hips was $78 \mathrm{~cm}$ $(88 \mathrm{~cm})$, chest girth was $106 \mathrm{~cm}(94 \mathrm{~cm})$, body length was 96 $\mathrm{cm}(84 \mathrm{~cm})$, hook bone width was $18 \mathrm{~cm}(17.5 \mathrm{~cm})$, chest width was $23 \mathrm{~cm}(18.6 \mathrm{~cm})$.

Young stock bred and grown at the farm under the same condition also follows parents' type and is characterized with a relatively early maturation. Measurements of nannies of 1.5 years of age comprised $94-98 \%$ of those of adult animals in height, $87 \%$ in body length, $94 \%$ in chest width, $87 \%$ in width of loin, $86 \%$ in chest girth.

So, one may conclude that the imported animals are uniform and pass their features well to offspring. In general, the animals at the farm are characterized with the built characteristic of the Saanen goats; sexual dimorphism is pronounced in adult animals and appears in the rearing stock at a young age.

\section{B. Growth and development indicators, herd reproduction}

One of important economic indicators is growth dynamics of young stock, as it is indicative of conforming to the young stock growth technology and reflects adaptive qualities of the animals. Changes in live weight during the growth, as well as formation following the type of the breed and general harmony of built allow speaking of adaptation and possibility of getting quality produce in the future $[10,11]$. Growth indicators of the rearing stock are given in Table 2.

TABLE 2 LIVE WEIGHT INDICATORS OF REARING NANNIES, KG

\begin{tabular}{|l|c|c|}
\hline \multicolumn{1}{|c|}{ Age } & $\begin{array}{c}\text { Recommended } \\
\text { for the breed } \\
\text { (elite class) }\end{array}$ & $\begin{array}{c}\text { Rearing } \\
\text { nannies } \\
\text { average }\end{array}$ \\
\hline At birth & 3.5 & 3.2 \\
\hline 1 month & - & 6.9 \\
\hline 6 months & 28 & 22.2 \\
\hline 18 months & 37 & 38.4 \\
\hline
\end{tabular}

Indicators of live weight changes of young nannies during their growth features a rather low-intensity growth during the first 6 months of their lives. In the end, by 6 months, the weight of the nannies comprised just $22.2 \mathrm{~kg}$, which is $5.8 \mathrm{~kg}$ less than the recommended value for the elite class and $3.8 \mathrm{~kg}$ less than that for the first class. However, later the growth rate increased, and by 18 months the nannies reached a weight of $38.4 \mathrm{~kg}$, which exceeds the elite class requirements ofr Saanen goats by $1.4 \mathrm{~kg}$ or $3.8 \%$.

This peculiar growth dynamics could be caused by the fact that the nannies in question were from the first kiddings of young goat mothers which were also living under unaccustomed climate. Besides, during the first 6 months, digestive system is being formed, which could also be reflected on the young stock. Later, growth stabilized and partially compensated, allowing getting quality rearing stock. It is confirmed by changes in live weight and previous measurements of the animals.

Another important indicator of development is the age of introduction of the young stock to the main herd. The first insemination for the Saanen breed is recommended at the age of $17-18$ months, which is followed at the farm. As a result, the age of the first kidding is $23-24$ months.

Round-the-year kiddings are performed at the farm. The load is 48 dams per a breeder buck on average. At that, young stock production fluctuated in the range of $135-167 \%$, which is less than the desired value of $180-200 \%$.

Thus, one may conclude that there are certain issues in young stock growing and herd reproduction, which may be explained by various factors, including relatively young age of the herd, possible upsets in the young stock growing and herd reproduction technology, ongoing adaptation to the new climatic zone.

\section{Goat milk productivity}

Milk productivity indicators and their passing down through generations indicate primarily stable inheritance and adaptation to specific breeding conditions $[12,13]$. Due to that, common formulas were used to calculate indicators of averages (X), mean square deviation $(\Sigma)$ and coefficients of variation $(\mathrm{Cv})$ for the main productive qualities of maternal ancestors of the imported nannies and the goat dams themselves (Table 3).

Analysis of productivity indicators expectedly showed that the highest milk yield was observed among mothers of fathers. 
Maternal ancestors of the imported goats were characterized by lower milk yield $(-348 \mathrm{~kg}$ or $27.9 \%$ less than mothers of fathers). In milk quality indicators, namely, milk fat and protein content, the mothers of the nannies exceeded other ancestors. At that, variation indicators of the productivity indicators were somewhat high only for milk fat content, indicating a certain degree of non-uniformity among mothers in this parameter.

Nannies of the farm demonstrated a lower milk yield than their maternal ancestors, by $246-594 \mathrm{~kg}(27.4-47.7 \%)$, but exceeded them in fat content by $0.62-0.69 \%$, while holding out in milk protein content. Besides, goat dams had the highest variation of all the milk productivity indicators.

TABLE 3 MILK PRODUCTIVITY OF NANNIES AND THEIR MATERNAL ANCESTORS

\begin{tabular}{|c|c|c|c|}
\hline Indicator & $\begin{array}{c}\text { Milk yield, } \\
\text { kg }\end{array}$ & Fat \%wt & $\begin{array}{c}\text { Protein, } \\
\text { \%wt }\end{array}$ \\
\hline \multicolumn{4}{|c|}{ Mothers (M) } \\
\hline $\mathrm{X}$ & 898 & 4.21 & 3.43 \\
\hline$\Sigma$ & 152.3 & 0.044 & 0.021 \\
\hline $\mathrm{Cv}, \%$ & 16.9 & 11.5 & 6.8 \\
\hline \multicolumn{4}{|c|}{ Mothers' mothers (MM) } \\
\hline $\mathrm{X}$ & 898 & 3.99 & 3.35 \\
\hline$\Sigma$ & 203.4 & 0.046 & 0.020 \\
\hline $\mathrm{Cv}, \%$ & 22.6 & 12.5 & 6.7 \\
\hline \multicolumn{4}{|c|}{ Fathers' mothers (MF) } \\
\hline $\mathrm{X}$ & 1246 & 4.06 & 3.34 \\
\hline$\Sigma$ & 222.1 & 0.055 & 0.024 \\
\hline $\mathrm{Cv}, \%$ & 17.8 & 15.0 & 7.9 \\
\hline \multicolumn{5}{|c|}{ Farm nannies (Daughters - D) } \\
\hline $\mathrm{X}$ & 652 & 4.68 & 3.43 \\
\hline$\Sigma$ & 177.7 & 0.960 & 0.925 \\
\hline $\mathrm{Cv}, \%$ & 27.3 & 20.5 & 26.9 \\
\hline
\end{tabular}

However, while the coefficient of variation for yield insignificantly exceeds allowable values of a well-adjusted herd (up to $25 \%$ ), for fat content and especially for protein content, these parameters are very high, meaning that there are specimens with very high quality characteristics of milk and those with very low characteristics. Coefficient of variation values of fat content and protein content exceeded the stable manifestation boundaries by a factor of 2 or 4 , meaning that a directed selection for these indicators of milk productivity is desired in the herd.

Despite overall reduction in milk productivity, there were animals in the herd with the milk yield of $800 \mathrm{~kg}$ and more, they comprised $7.5 \%$ of the total head count. At than, one shall take into account that milk productivity in goats continues growing through the first 4 lactations, while at the moment of assessment the age of herd was only 2 lactations.

Thus, one may conclude that despite a significant effect of changes in feed (Tyumen oblast is characterized by fodder that is deficient in proteins) and ongoing adaptation, the animals cope with adaptation well.

\section{Interrelations of the productive qualities of goats}

Development of any herd depends on the degree to which the progeny inherits productivity attributes of their mothers. Data on productivity of mothers and mothers' mothers of the dams, as well as other mothers and dams in the farm were used to calculate heritability coefficients for the productivity indicators (Table 4).

TABLE 4 HERITABILITY COEFFICIENT OF PRODUCTIVITY PROPERTIES IN NANNIES, $\mathrm{H}^{2}$

\begin{tabular}{|l|c|c|}
\hline \multicolumn{1}{|c|}{ Property } & MM $-\mathbf{M}$ & M - D \\
\hline Milk yield, kg & $0.367^{*}$ & 0.192 \\
\hline Fat, \%wt & $0.648^{* *}$ & $0.608^{* *}$ \\
\hline Milk fat, kg & $0.457^{* *}$ & 0.034 \\
\hline Protein, \%wt & $0.969 * * *$ & $0.341^{*}$ \\
\hline Milk protein, kg & $0.454^{* *}$ & $0.340^{*}$ \\
\hline
\end{tabular}

represented by * - $\mathrm{P}<0.05 ; * *$ - $\mathrm{P}<0.01$; *** $-\mathrm{P}<0.001$

The obtained heritability indicators for milk productivity in the $\mathrm{MM}-\mathrm{M}$ generation indicate stable inheritance and an open possibility to improve the herd by means of massive selection. However, in the $\mathrm{M}-\mathrm{D}$ generation there is a reduction of the parameters observed, explained by a strong effect of abrupt changes in environmental factors. The changes in the environmental background did not allow full realization of the animals' genetic potential. However, even in this case the preserved heritability indicators allow inferring a rather well descending inherited foundation.

Taking into account relations between various indicators that characterize milk productivity of animals is equally important in subsequent operation of the herd (Table 5).

TABLE 5 RELATIONS BETWEEN THE PRODUCTIVE INDICATORS OF NANNIES

\begin{tabular}{|l|c|}
\hline \multicolumn{1}{|c|}{ Property } & r \\
\hline Milk yield, kg - Daily milk yield, kg & $0.825^{* * *}$ \\
\hline Milk yield, kg - Fat, \%wt & $-0.295^{*}$ \\
\hline Milk yield, kg - Milk fat, kg & $0.796^{* * *}$ \\
\hline Milk yield, kg - Protein, \%wt & -0.005 \\
\hline Milk yield, kg - Milk protein, kg & $0.854^{* * *}$ \\
\hline Fat, \%wt - Protein, \%wt & 0.012 \\
\hline Milk fat, kg - Milk protein, kg & 0.660 \\
\hline Daily milk yield, kg - Fat, \%wt & -0.124 \\
\hline Daily milk yield, kg - Milk fat, kg & $0.736^{* * *}$ \\
\hline Daily milk yield, kg - Protein, \%wt & -0.011 \\
\hline Daily milk yield, kg - Milk protein, kg & $0.688^{* * *}$ \\
\hline
\end{tabular}

Established correlation coefficients indicate presence of reliable and strong positive relation between the quantitative indicators, which will allow performing selection for milk yield 
and daily milk yield. At that, milk yield had negative correlation with quality characteristics of milk, either as a weak link, or as a trend, the latter being preferable, as it indicates unstable relation with an open possibility to redirect it in a positive direction with subsequent fixation.

Only animals with harmonious development have the best possibilities for realizing high productivity [14]. Despite lack of direct link between animal exterior and animal productivity, there is always an indirect link. The obtained correlation coefficients confirm this relation (Table 6).

TABLE 6 CORRELATION BETWEEN EXTERIOR INDICATORS AND MILK PRODUCTIVITY

\begin{tabular}{|l|c|c|}
\hline \multirow{2}{*}{\multicolumn{1}{|c|}{ Measurement }} & \multicolumn{2}{|c|}{ Correlation coefficient with } \\
\cline { 2 - 3 } & yield per lactation, kg & yield per day, kg \\
\hline Height at the withers & $0.259^{* *}$ & $0.282^{* *}$ \\
\hline Height at hips & $0.316^{* * *}$ & $0.274^{* *}$ \\
\hline Diagonal body length & $0.320^{* * *}$ & $0.224^{*}$ \\
\hline Chest width & $0.276^{* *}$ & $0.370^{* * *}$ \\
\hline Chest girth & $0.356^{* * *}$ & $0.232^{*}$ \\
\hline Hook bone width & $0.203^{*}$ & 0.032 \\
\hline
\end{tabular}

The revealed relations allow stating that directed selection of large, well-developed animal will allow not only increasing productivity, but also selecting the specimens most adapted to milk production.

\section{E. Immunogenotypic characteristic of the herd for the polymorphic systems of proteins and enzymes}

Permanence of polymorphic protein and enzyme types in ontogeny and inheritance following a code dominance principle allow using them for genetic characteristic of populations, origins analysis of breeds, lines, families, determination of genetic similarity, control of origin records $[15,16]$.

The immunogenotypic research was conducted for four polymorphic systems of blood proteins and enzymes: transferrin (Tf) protein of blood plasma - carrier of iron, hemoglobin $(\mathrm{Hb})$, serum arylesterase (AEs) and alkaline phosphotase (Ap). The analysis results have shown, that the animals of the herd are carriers of two alleles in the loci of transferrin, $\mathrm{Tf}^{\mathrm{D}}$ and $\mathrm{TF}^{\mathrm{E}}$, hemoglobin $\mathrm{Hb}^{\mathrm{B}}$ and $\mathrm{Hb}^{\mathrm{C}}$, serum arylesterase $\mathrm{AEs}^{\mathrm{H}}$ and $\mathrm{AEs}^{\mathrm{B}}$ and two alleles of the alkaline phosphatase locus, $\mathrm{Ap}^{\mathrm{A}}$ and $\mathrm{Ap}^{\mathrm{B}}$.

Out of 12 complex phenotypic combinations possible with four polymorphic systems of blood proteins and enzymes, only 8 were detected. The most common phenotypic combinations were $\mathrm{DD} \mathrm{BB} \mathrm{HB} \mathrm{AB}(61.7 \%)$, DD BB HB BB (13.5\%) and DDBCHBAB (12.8\%), rare ones were DE BB HB AA $(0.7 \%)$ и $\mathrm{DEBCHBAB}(0.7 \%)$. No instances of the following combinations were found: DD BC HB AA, DE BC HB AA, DD $\mathrm{BB} \mathrm{HB} \mathrm{AA}$ and DE BC HB BB.

In transferrin locus, allele D had the highest occurrence frequency $(94-97 \%)$; in hemoglobin locus, allele B had the highest frequency $(87-94 \%)$, at that concentration of these alleles has increased in nannies. In enzyme loci, no such significant difference in allele occurrence was observed. For example, in arylesterase locus, occurrence of $\mathrm{H}$ and $\mathrm{B}$ alleles is absolutely the same, which is characteristic of the Saanen breed. In the alkaline phosphatase locus, occurrence of B allele (58$61 \%$ ) was insignificantly higher than the A allele (39-42\%), while in a certain group of nannies, occurrence of these alleles was an average from the parental forms.

Occurrence of polymorphic phenotypes is given in Table 7.

TABLE 7 OCCURRENCE FREQUENCY OF PHENOTYPES OF POLYMORPHIC SYSTEMS, $\%$

\begin{tabular}{|c|c|c|c|c|}
\hline \multirow[b]{2}{*}{ Locus } & \multirow[b]{2}{*}{ Phenotype } & \multicolumn{3}{|c|}{ Group } \\
\hline & & $\begin{array}{c}\text { He-goats } \\
(n=19)\end{array}$ & $\begin{array}{c}\text { Dams } \\
(n=61)\end{array}$ & $\begin{array}{c}\text { Young } \\
\text { nannies } \\
(n=61)\end{array}$ \\
\hline \multirow{2}{*}{$\mathrm{Tf}$} & DD & 0.89 & 0.88 & 0.94 \\
\hline & $\mathrm{DE}$ & 0.11 & 0.12 & 0.06 \\
\hline \multirow{2}{*}{$\mathrm{Hb}$} & $\mathrm{BB}$ & 0.74 & 0.83 & 0.87 \\
\hline & $\mathrm{BC}$ & 0.26 & 0.17 & 0.13 \\
\hline AEs & HB & 1.00 & 1.00 & 1.00 \\
\hline \multirow{3}{*}{ Ap } & $\mathrm{AA}$ & 0.00 & 0.00 & 0.02 \\
\hline & $\mathrm{AB}$ & 0.79 & 0.83 & 0.79 \\
\hline & BB & 0.21 & 0.17 & 0.19 \\
\hline \multicolumn{2}{|c|}{ Degree of homozygosis, SH } & 0.49 & 0.39 & 0.41 \\
\hline
\end{tabular}

Two phenotypes, DD and DE, have formed in the transferrin locus; the frequency of homozygonic variant was higher; due to that, homozygosis of the locus increased in progeny as compared to their parents. A similar situation was observed with the hemoglobin locus: the highest frequency is characteristic of the homozygotic $\mathrm{BB}(74-87 \%)$ and its frequency increases in progeny.

In the arylesterase enzyme locus, only one HB phenotype was established, with the same frequency in all sex and age groups. Locus of alkaline phosphotase has three phenotypes: $\mathrm{AA}, \mathrm{AB}$ and $\mathrm{BB}$. The highest occurrence was registered for the heterozygotic phenotype $(79-83 \%)$, homozygotes in the $\mathrm{B}$ allele were rarer at $17-21 \%$, while variability of phenotypes was stable among all the sex and age groups. The AA variant was found only among nannies and was very rare.

Degree of homozygosis calculated for four loci in various sex and age groups was at a level of 39 and $49 \%$ for the parent herd and $41 \%$ for the female progeny. This degree of homozygosis may be considered average.

Thus, studies of blood protein and enzyme polymorphism indicate a high degree of herd uniformity, which in its turn is an evidence of its pedigree nature and speaks of necessity to introduce some new blood.

\section{CONCLUSION}

Thus, Saanen goats imported to Tyumen oblast form Germany were able to adapt to new climatic conditions. The degree of adaptation may be considered average, as the animals were not able to show the values typical of their breed in all the indicators, which is further supported by the following: 
- growth indicators of the rearing stock indicate a possibility to obtain high-quality young stock meeting the requirements of elite class for the Saanen breed;

- in reproductive indicators, we observed timely introduction of the rearing nannies into the main herd with the age of the first kidding at $23-24$ months, but insufficient young stock output at $135-167 \%$ as calculated for 100 goat dams, with the value of $180-200 \%$ typical of the Saanen breed;

- the goats at the farm showed inferior results than the indicators of their maternal ancestors in milk productivity by $246-594 \mathrm{~kg}$ or $27.4-47.7 \%$ (which is explained by many factors including the young age of dams), but has shown higher fat $(+0.62+0.69 \%)$ and protein $(0+0.09 \%)$ content of their milk;

- animals imported to the farm could not realize their genetic potential to the full extent, the heritability coefficients of milk productivity indicators in the mother-daughter generation reduced as compared to that in mother's mother - mother generation;

- correlation links between the milk productivity indicators have reduced in comparison with the maternal ancestors, but in general they kept their direction, allowing selection of animals by yield, including daily yield;

- selection of nannies basing on their exterior also guarantees obtainment of high-yield pedigree animals, which is supported by established positive relations between the goat measurements and their productive qualities;

- exterior of imported dams and breeders mainly complies with the breed type, while having its own specifics (relatively low height, elongated body and sizable chest) that is passed down to progeny;

- studies of polymorphism in blood proteins and enzymes revealed a high level of uniformity of the imported animals, thus not only confirming its breed but also allowing recommending to add some fresh blood with the aim to increase the genetic variability of the herd.

\section{References}

[1] M.A. Chasovshchikova, O.M. Sheveleva, M.A. Svjazhenina, Tatarkina N.I., Satkeeva A.B. Relationship between the genetic variants of kappacasein and prolactin and the productive-biological characteristics of cows of the black-motley breed. Journal of Pharmaceutical Sciences and Research, 2017, Vol. 9, No. 7, pp. 1038-1044.

[2] S.I. Novopashina, M.Yu. Sannikov, Prospects of development and scientific support of daily and meat goat farmin in Russia, Ovtsy, kozy, sherstyanoye delo, 2013, no. 2, pp. 61-65.

[3] I. Novitsky, Angora goat: Prospects and peculiarities of breeding Selkhozportal, 2016, November Access mode: https:/сельхозпортал.pф/articles/angorskaya-poroda-koz/\#a1

[4] E.A. Ponomareva, M.A. Svyazhenina, N.I. Tatarkina, Milk goat farming in Tyumen oblast, Glavnyi Zootekhnik, 2015, no. 10, p. 68-72.

[5] T. Kozhanov, Milk goat farming in Russia: Progress in selection and processing, Sfera: Molochnaya promyshlennost, 2017, no. 1 (60), pp. 42 -44 .

[6] T.V. Kozhanov, Goat farming at the national scale, Molochnaya promyshlennost, 2015, no. 6, p. 64.

[7] Gukezhev V.M., Gabayev M.S., Zhazhuyev Zh.Kh. Adaptive abilities of Saanen goats to various zones of breeding / Collected: Prospective developments in Agro-Industrial Complex Materials of the International Science Practical Conference. 2017. p. 48 - 53.

[8] V.K. Toschev, G.N. Mustafina, Milk goat farming and its developmen prospects with Saanen goats of domestic reproduction, Zootechnia. 2011, no. 5 , pp. $26-27$

[9] V.K. Toschev, G.N. Mustafina, Using Saanen goats to improve milk goat farming, Agrarnaya nauka, 2012, no. 5, pp. $27-28$.

[10] O. Mashner, P. Lyutskanov, I. Tofan, Yu. Sannikov, C. Novopashina, Manual for valuation of milk goats with elements of selective breeding. Access mode https://fermer.ru/forum/plemennaya-rabota-igenetika/116514

[11] Draft decree of the Ministry of Agriculture of the Russian Federation «On approving procedure and conditions for valuation of pedigree milk goats Access mode http://www.garant.ru/products/ipo/prime/doc/56641888/

[12] O.K. Gogayev et al. Milk productivity of Saanen goats in conditions of foothils of North Osetia-Alania, Annals of Gorsky State Agricultural University, 2014, Vol. 51, no. 1, pp. $43-49$.

[13] Yu. N. Perevalov, N.V. Bodrova, A.S. Shuvarikov, O.N. Pastukh, Milk productivity and milk quality of Saanen goat of various parental ancestry, Zootechnia, 2011, no. 3, pp. $31-32$

[14] Novopashina, S.I., Sannikov M.Yu., Bulatov A.S. Relations between the milk productivity of Saanen goats and their exterior and interior scores / Collection of papers of Stavropol R\&D Institute of Animal Breeding and Feed Production. 2004. Vol. 2. no. 1 p. $53-56$

[15] L.V. Olkhovskaya, S.I. Novopashina, M.Yu. Sannikov, Using immunity genetic indicators in selection of milk goats, Collection of papers of the All-Russian R\&D Institute of Sheep and Goat Breeding, 2007, no. 3, pp. $23-26$.

[16] L.V. Olkhovskaya, S.I. Novopashina, M.Yu. Sannikov, S.V Krivoruchko, Peculiarities of allele stock of various population of Saanen goats, Ovtsy, kozy, sherstyanoye delo, 2011, no. 4, pp. $23-26$ 